\title{
Lending Conditions and Marketing Strategies Of Financial Institutions in Kosovo to Support Access to Finance for Women Entrepreneurs
}

\author{
${ }^{1}$ Ajtene Avdullahi, ${ }^{2}$ Vjosa Fejza Ademi \\ ${ }^{1}$ University of Mitrovica Isa Boletini, Kosovo \\ ${ }^{2}$ University of Prishtina Hasan Prishtina, Kosovo \\ 1ajtene.avdullahi@umib.net, ${ }^{2}$ vjosa.fejza@uni-pr.edu
}

\begin{abstract}
Purpose: The main purpose of this paper is to investigate the effort of financial institutions that support female entrepreneurship in a developing economy as well as the marketing strategies that those financial institutions utilize to increase the awareness of the female entrepreneurs concerning their preferential lending conditions and terms.

Design/methodology/approach: For our research purpose the secondary data are used such as research papers, books and reports. The comparative method is used to compare the financial institutions lending conditions as well as the marketing and promotional strategies of those institutions.

Findings: Access to finance presents one of the main barriers for female entrepreneurs in developing countries. Our results indicate that not so many financial institutions are constantly offering preferential lending conditions and terms for female-owned enterprises.

Practical implications: We propose that financial institutions need to increase the number of loans and credit packages that support women's entrepreneurship and to create and promote much more marketing plans and strategies for women financial support packages from banks, to raise awareness of women entrepreneurs regarding the preferential lending conditions and special offers.
\end{abstract}

Paper type: Research paper

Keyword: Access to finance, Female entrepreneurship, Marketing strategies

\begin{tabular}{lll}
\hline Received & $:$ December $9^{\text {th }} 2019$ \\
Revised & $:$ February $12^{\text {th }} 2020$ \\
Published & $:$ March $30^{\text {th }} 2020$ \\
\hline
\end{tabular}

Lending policy and marketing strategies of financial institutions in Kosovo to support access to finance for women entrepreneurs 


\section{INTRODUCTION}

Entrepreneurship is seen as an essential driver of societal health and wealth, and a formidable engine of economic growth (Bosma, et al., 2020). The earlier literature has considered entrepreneurship to be a youth and male-dominated sector (Berg, 1997; Brush, 1992). Nowadays, entrepreneurship is more inclusive considering that the number of female and middle-age entrepreneurs is increasing. This is mainly due to the large enterprise's staff reduction as a process of labor force substitutes with automatization of production and service digitalization aiming to reduce costs and increase profits. As a result of this, mainly the older staff are reduced and pushed to start their own business. Besides, every day more and more women and men want to pursue their dreams, start their businesses, be independent and, become bosses of their enterprise. However, the early stages of business creation are usually followed by many obstacles that derive from external factors of the business environment but also internal factors. In developing and transition economies the main obstacles to business, faced by entrepreneurs are the informal economy, corruption, and access to finance rather than internal factors such as managerial or employee's skills (Avdullahi, 2014).Governments are trying to create different policies to support entrepreneurs, given that the businesses they create come to place with numerous benefits to the country such as innovation, economic development, and unemployment reduction. In particular, a special focus is given to female entrepreneurship. Although so much has been done, discussed and lobbied toward supporting and boosting women entrepreneurship, still, worldwide female entrepreneurs lag behind male counterparts in firm creation and management. Many economies still underestimate women entrepreneurship and do not create policies and business environments that support women entrepreneurs. According to Radović-Marković (2015), the impact of female entrepreneurs on a country's competitiveness, productivity and growth potentials was not known, thus, women were not supported by society to reach their entrepreneurial and managerial potential. The benefits of having more women entrepreneurs are numerous. The rising phenomenon of women becoming entrepreneurs not only encourages economic development but also empowers women (Gill \& Ganesh, 2007). Female entrepreneurs contribute to the diversity of entrepreneurship in the economic process (Verheul \& Thurik, 2001). In addition, in most of the transition and developing countries, barriers to gender entrepreneurship development still exist (Bosma, et al., 2020). According to Ramadani, et al., (2013) women entrepreneurs need appropriate assistance both in business running and development. Young firm's growth and survival very often are threaten and limited from financing constraints (Brown \& Earle, 2015; Cosh, et al., 2009) considering that finance is the lifeblood of business (Bhagchandka, 2019). Access to finance is found to be the greatest challenge faced by women in starting and operating Cottage, Micro, Small and Medium Enterprises in Bangladesh (Chowdhury, 2019). Similarly, in Lebanon the main barrier to

Lending policy and marketing strategies of financial institutions in Kosovo to support access to finance for women entrepreneurs 
increasing the participation of women in business remains access to finance (IFC, 2013).

\section{A. Literature Review}

Although this constraint is universal for all Small and Medium Enterprises (SMEs), regardless of gender, in developing economies it tends to affect more female entrepreneurs. Whereas, women own more than 30 percent of all smaller businesses in the developing world, but in Lebanon, only 3 percent of bank loans go to female entrepreneurs (IFC, 2013). In addition (Brock \& De Haas, 2019) tested for the presence of gender discrimination in small business lending and found that loan officers are 30 percent more likely to make the loan approval conditional on the presence of a guarantor for applications coming from a female instead of a male entrepreneur. The literature reviewed above mainly focuses on the barriers of entrepreneurs, especially female entrepreneurs, identifying access to finance as the main barrier for women entrepreneurs in developing countries. Although numerous papers investigate and propose strategies on access to finance, for female entrepreneurs. Women are considered to play a growing role in entrepreneurship all over the world (Imhonopi, et al., 2013). According to Morse (1973), failure to pay attention to women's economic activities is both morally indefensible and economically absurd. Improving the opportunities of women to economic activities is a major requirement for developing countries to achieve increased levels of economic growth and development (Imhonopi, et al., 2013). According to Imhonopi, et al., (2013), these extensive development benefits were duly recognized by the World Bank's Gender Equality Action Plan for 2007-2010 where it was stated that the global community must renew its attention to women's economic empowerment and increase investments in women. However, as the contribution of women to economic development is well documented, Sanusi (2012) in his recent treatise observed that there still exist several barriers to the full optimization of women's economic potential. These range from cultural to religious, traditional, and legal discrimination, among others (Imhonopi, et al., 2013). One of these barriers that women entrepreneurs face is access to finance. Still, there is a gap in the literature regarding the effort of financial institutions to support female entrepreneurship by facilitating lending policies in terms of not asking collateral pledged and guarantor to secure a loan as well as offering preferential rates for loans and credit cards. Therefore, in this paper we try to investigate the effort of financial institutions to support female entrepreneurship in a developing economy such as Kosovo scenario. Besides, this paper aims to investigate the marketing strategies that those financial institutions utilize to increase the awareness of the female entrepreneurs concerning their preferential lending conditions.

\section{B. Hypothesis}

Access to finance presents one of the main barriers for female entrepreneurs in developing countries.

Lending policy and marketing strategies of financial institutions in Kosovo to support access to finance for women entrepreneurs 


\section{METHODOLOGY}

For the research purpose of this paper, we have used the desk research technique by reviewing the existing relevant literature such as research papers, books, and reports. The data from Kosovo Statistics Agency (KAS), World Bank and Kosovo Business Registration Agency as well as Central Bank of Kosovo will be used to identify the number of businesses owned by females in Kosovo, number of registered and terminated businesses as well as the number of financial institutions by years. For our research purpose, we will use the data from Financial Institutions in Kosovo web pages which offer preferential lending conditions aiming to boost female entrepreneurship in Kosovo.

The comparative methods are widely used in social sciences research. Researchers compare the relative effects of variables across cases; they compare cases directly with one another; and they compare empirical cases with counterfactual cases (Ragin \& Rubinson, 2009). In our research paper, we have used the comparative method to compare the financial institutions lending conditions as well as the marketing and promotional strategies of those institutions.

\section{RESULTS AND DISCUSSIONS}

The role of SMEs is well known in the economies of different countries worldwide. SMEs are recognized as a source of innovation, employment and economic development. In Kosovo only about 20 percent of the jobs are generated by the public sector, the rest of the employment comes from the private sector respectively SMEs. In table 1 are presented the number of new registered as well as the number of terminated enterprises for the period 2007-2018. The largest number of registered businesses is in 2016 with 10424 new businesses. However, the highest number of terminated businesses was recorded in this year (2350 businesses) during the period 2007-2018 (KAS, 2019).

\begin{tabular}{ccc}
\multicolumn{3}{c}{ Table 1- Number of registered and terminated enterprises by years 2007-2018 } \\
\cline { 1 - 3 } Year & New enterprises & Terminated Enterprises \\
\hline 2007 & 6124 & 1205 \\
2008 & 7557 & 943 \\
2009 & 7505 & 1136 \\
2010 & 7729 & 1363 \\
2011 & 7879 & 924 \\
2012 & 9592 & 1081 \\
2013 & 9421 & 1434 \\
2014 & 9405 & 1669 \\
2015 & 9811 & 2170 \\
2016 & 10424 & 2350 \\
2017 & 9223 & 1613
\end{tabular}

Lending policy and marketing strategies of financial institutions in Kosovo to support access to finance for women entrepreneurs 


$\begin{array}{ccc}2018 & 9805 & 1418 \\ \text { Source: } K A S, 2019 & \end{array}$

According to the KAS report (2019), 9805 new enterprises were registered in 2018, whereas 98.8 percent were Micro enterprises, 1.1 percent were Small enterprises, 0.1 percent were Medium enterprises. While, as can be seen in Table 2 , this year no Macro enterprise was registered.

Table 2- Number of SMEs in 2018

\begin{tabular}{|c|c|c|c|c|}
\hline Classification & \multicolumn{2}{|c|}{ Numer of employees } & Number of enterprises & $\%$ \\
\hline Micro Enterprises & $1-9$ & workers & 9.683 & 98.8 \\
\hline Small Enterprises & $10-49$ & workers & 112 & 1.1 \\
\hline Middel Enterprises & $50-249$ & workers & 10 & 0.1 \\
\hline Macro Enterprises & 250 and over & workers & 0 & 0 \\
\hline Total & & & 9.805 & 100.0 \\
\hline
\end{tabular}

In figure 1 are presented the number of businesses with the female owner by years 2014-2018. As can be seen in the graph the number of female entrepreneurs is increasing by years reaching 997 business with female owners in 2018 (World Bank, 2020).

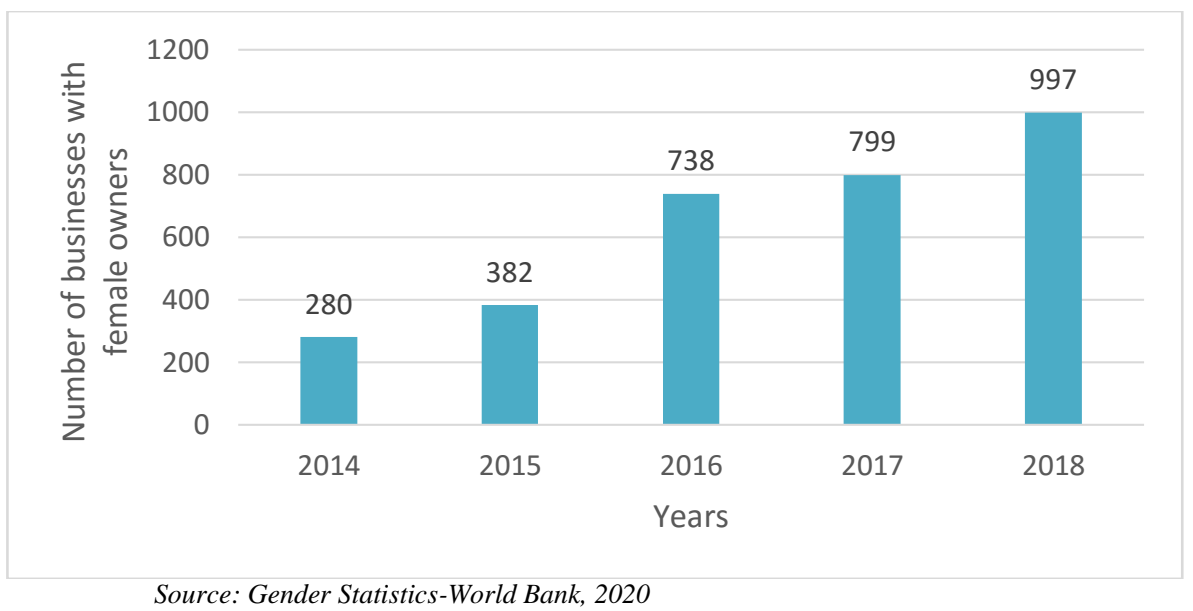

Figure 1- Number of business with female owners over the years 2014-2018

According to KBRA (2020), gender participation in business organizations registered during 2019 for individual businesses that usually are micro or small businesses and have a single owner is very small. During 2019, the percentage of businesses with the female owner has reached a maximum value in October with 36 percent. Whereas, the percentage of gender participation is even smaller in other legal forms of business organizations whose owners are partners or shareholders in larger or more diverse business organizations reaching the highest value in September and October 2019 with 21 percent (KBRA, 2020).

Table 3 - The number of financial institutions in Kosovo

Lending policy and marketing strategies of financial institutions in Kosovo to support access to finance for women entrepreneurs 


\begin{tabular}{|l|c|c|c|c|c|c|c|c|c|c|}
\hline Description & Jun-10 & Jun-11 & Jun-12 & Jun-13 & Jun-14 & Jun-15 & Jun-16 & Jun-17 & Jun-18 Jun-19 \\
\hline Commercial banks & 8 & 8 & 8 & 9 & 10 & 10 & 10 & 10 & 10 & 10 \\
\hline Insurance companies & 11 & 11 & 13 & 13 & 13 & 15 & 15 & 15 & 15 & 13 \\
\hline Pension funds & 2 & 2 & 2 & 2 & 2 & 2 & 2 & 2 & 2 & 2 \\
\hline Microfinance Institutions and Banks & 17 & 17 & 19 & 18 & 18 & 18 & 18 & 17 & 21 & 23 \\
\hline Financial auxiliaries & 29 & 32 & 39 & 40 & 41 & 43 & 46 & 49 & 53 & 53 \\
\hline \multicolumn{1}{|c|}{ Source }
\end{tabular}

The financial system in Kosovo mainly consist of Commercial banks, Insurance companies, Microfinance institutions and banks, Pension funds and financial auxiliaries.

The banking sector is dominated by EU origin capital accounting for 57.5 percent of total banking sector assets, followed by the banks from Turkey with 16.9 percent of the sector's assets and other countries (CBAK, 2019).

From 10 Commercial banks operating in Kosovo market, there is only one bank that is constantly offering preferential lending conditions and terms for female-owned enterprises. This commercial bank for the first time in the banking sector of Kosovo started to offer loans to finance women that are older than 18 years and that have feasible ideas to launch their business. The bank offered promotionally loans called Start-Up Business Loans (START-UP) (TEB, 2020). Usually, commercial banks hesitate to finance Start-up considering the high risk or take high measures to secure the loan with a guarantor or asking to pledge collateral (movable or mortgage). Aiming to boost female entrepreneurship this bank is offering the financial package for women with the following preferential conditions: Start-up loan, Support to sustainable development through consulting with their partners, Grace period of up to three months for start-up businesses (TEB, 2020). For most entrepreneurs, the hardest phase is their business career is the preparation phase to launch a new service or product and thus start-up their business, therefore this bank decided to support new ventures and thus reduce the risk of repaying the loan by offering consultancy. Besides, aiming to reduce the nonperforming loans, the bank offers to all female business clients who are regular in credit installment payments until the end of the credit cycle 10 percent refund of interest paid (TEB, 2020). Supporting and investing in women entrepreneurs brings benefits to society, community, and the family. As Akin Adesina (2018), the President of the African Development Bank stated: "Women re-invest up to 90 percent - yes, 90 percent - of their income in their families and communities. That money goes into feeding and providing better nutrition for children, educational expenses, and in paying for doctor's visits". Considering the crucial importance of investing and motivating women to start and run their business this bank for the International women's added to the START-UP package, 60 percent consulting amount coverage European Bank for Reconstruction and Development (TEB , 2020).

From 23 Microfinance Institutions and banks operating in Kosovo only two of them are offering preferential lending conditions and terms for female entrepreneurs. One microfinance institution provides loans to women 
entrepreneurs up to $€ 25,000$ with duration of up to five years (FINCA, 2020). Starting the business sometimes requires many investments even some nonanticipated expenses may appear, which makes it harder for the entrepreneurs to start paying their loan installment. This is also foreseen on the package that the Microfinance is offering and thus the grace period for businesses with female owners up to 3 months is offered, whereas for female entrepreneurs in the agriculture the grace period up to 12 months is offered.

In Kosovo most of women do not own property to pledge as loan collateral, without collateral and without a mortgage, sometimes the bank is the end of the road for many women entrepreneurs (Akin Adesina, 2018). Therefore the package for businesswomen for the amounts up to 5,000€ do not ask for a guarantee, neither to pledge collateral - women can apply only on with their identification cards (FINCA, 2020).

Another Microfinance institution offers loans with up to 6 months grace period and in amount up to $€ 25,000$ (AFK, 2020).

Based on our research we found that none of the banks do offer business credit cards for female entrepreneurs. Some banks are having some promotional offers such as one of the foreign banks operating in Kosovo is offering to female clients regular credit cards plus an additional credit card called "SheCard" thus enabling two parallel credit card limits only for female clients, as well as additional promotional benefits (TEB, 2020). Another bank offers credit bonus cards for the female with an extra beautiful design but with the same conditions as for male bonus credit cards expect for some holidays such as women's international day provides promotional offers such as 10 percent discount to perfumery and cosmetics merchants (Raiffeisen bank, 2020).

\section{CONCLUSION}

Although existing literature extensively investigates entrepreneurship and female entrepreneurship from a range of different disciplines, it is notable that the literature exploring the lending conditions of women entrepreneurs are scarce. Therefore, by reviewing the existing literature and investigating the offerings of financial institutions in Kosovo we tried to identify what are the lending terms and conditions to women entrepreneurs in a developing economy and thus to contribute to filling the gap in the existing literature. Based on our research we found that the role of women entrepreneurs in Kosovo is crucial and comes with numerous benefits for the woman, her family, and society. Akin Adesina (2018) rightly confirm that investing in women creates a true multiplier effect for communities but, still we somehow fail to connect the dots. Whether they are involved in small or medium scale production activities, or in the informal or formal sectors, women's entrepreneurial activities are not only a means for economic survival but also have social consequences for the women themselves and their social environment (Alutu \& Uzamere, 2011). Despite this, not enough has been done to improve this situation. Women entrepreneurs face

Lending policy and marketing strategies of financial institutions in Kosovo to support access to finance for women entrepreneurs 
different obstacles, and access to finance is one of them. Loan approval from financial institutions requires a guarantee, depending on the amount it requires to pledge movable collateral, whereas sometimes and mortgage. Considering that it is hard for women to fulfill these criteria, some changes must be made. It presents a status quo that must change - Not because it's a charity or the right thing to do - although it most certainly is the right thing to do - but because it's the smart thing to do and it's the strategic thing to do (Akin Adesina, 2018). From all financial institutions in Kosovo, only three of them offer lending products and packages with preferential terms and conditions to support female entrepreneurs and boost female entrepreneurship. Considering this we propose to increase the number of loans and credit packages that support women's entrepreneurship. Investors like banks and financial institutions often hesitate to finance start-ups with women on board; viewing them as a risk of return and as a factor that may affect the growth of nonperforming loans. Therefore, there is a need for these institutions to cooperate with the Government and / or large investment banks as is the case in Kosovo to implement joint programs aimed at improving the financial environment and ensuring a variety of financial instruments and incentives that will help women run their businesses (Ramadani, et al., 2013).

Besides, we propose to create and promote much more marketing plans and strategies for women's financial support packages from banks, to be informed well and to raise awareness of women for special offers that exist. Also, marketing is crucial for gathering information regarding the needs and demands of the targeted market, namely financial support needed from women in SMEs. In particular, successful institutions have been able to adapt their marketing materials to reflect women's needs, often incorporating women-to-women communications (Berfond, et al., 2014). Programs usually have dedicated websites tailored to women, including photos depicting women entrepreneurs, Start-up packages, terminology adapted to entry-level customers (including local languages and illustrations), and benefits and discounts for women (Berfond, et al., 2014). In general, communications are advertised where women live and work, and focus on women-specific sectors and industries.

\section{ACKNOWLEDGMENTS}

This paper has no conflict of interest.

\section{REFERENCES}

AFK, 2020. AFK. [Online] Available at: https://www.afkonline.org/kredindermarrese.html

Akin Adesina, 2018. The African Development bank. [Online] Available at: https://www.afdb.org/en/news-and-events/what-could-women-do-with-3billion-18496

Lending policy and marketing strategies of financial institutions in Kosovo to support access to finance for women entrepreneurs 
Alutu, A. N. G. \& Uzamere, A. O., 2011. The Girl-Child and Entrepreneurial Education: A Case for Economic Sustainability.. Current Research Journal of Social Science, 3(3), pp. 180-187.

Avdullahi A. 2015. Obstacles to small and medium enterprises. Horizons 17 pp $67-76$

Berfond, J., Haas, E., Rodrigues, H. \& Wahler, B., 2014. Global best practices in banking for women-led SMEs, s.1.: European Bank for Reconstruciton and Development (EBRD).

Bhagchandka, M., 2019. Gender Gap: How to overcome the 6 Barriers Faced by Women Entrepreneurs, New Delhi: s.n.

Bosma, N. a iní, 2020. Global Entrepreneurship Monitor 2019/2020 Global Report, London: Global Entrepreneurship Research Association, London Business School.

Brock, J. M. \& De Haas, R., 2019. Gender discrimination in small business lending. Evidence from a lab in the field experiment in Turkey. European Bank for Reconstruction and Development EBRD, Zväzok Working Paper No. 232, pp. 1-46.

CBAK, 2019. Financial Stability Report, Number 15, Prishtina: Central Bank of Kosovo.

Chowdhury, D. S., 2019. Financing female entrepreneurs in cottage, micro,small, and medium enterprises: Evidence from the financial sector in Bangladesh 2010-2018. Asia \& Pacific Policy Studies, Zväzok 6, p. 397-416..

FINCA, 2020. FINCA Kosovo. [Online]Available at: https://www.fincakosovo.org/en/products/women-entrepreneur-loan/

Gill, R. \& Ganesh, S., 2007. Empowerment, constraint, and the entrepreneurial self: A study of white women entrepreneurs. Journal of Applied Communication Research, 35(3), p. 268-293.

IFC, 2013. Business lines: Access to finance, Beirut: World Bank Group IFC.

Imhonopi, D., Urim, U. M. \& Ajayi, M. P., 2013. Increasing the access of women entrepreneurs to finance in Nigeria. A panoply of readins in social sciences: Lessons for and from Nigeria, pp. 387-408.

KAS, 2019. Statistical Yearbook of the Republic of Kosovo, Prishtina: Kosovo Agency of Statistics.

KBRA, 2020. Basic Performance Indicators report on business registration in Kosovo for 2019, Prishtina: Kosovo Business Registration Agency.

Morse, F. B., 1973. A better Way? A speech delivered to the United Nations $(U N)$, Minnesota: Association of Minnesota.

Raiffeisen bank, 2020. Raiffeisen Bank Kosovo. [Online] Available at: https://www.raiffeisen-kosovo.com/eng/individuals/products-andservices/cards/bonus-cards/

Ramadani, V., Gërguri, S., Dana, L.-P. \& Tašaminova, T., 2013. Women entrepreneurs in the Republic of Macedonia: Waiting for directions.

Lending policy and marketing strategies of financial institutions in Kosovo to support access to finance 
International Journal of Entrepreneurship and Small Business, 19(1), pp. 95121.

Sanusi, L. S., 2012. Increasing Women's Access to Finance: Challenges and Opportunities.. Lagos, Nigeria, A paper presented by the Governer of the Central Bank at the Second African Women's Economic Summit.

TEB , 2020. TEB Sh.A. [Online] Available at: https://www.teb-kos.com/

Verheul, I. \& Thurik, R., 2001. Start-up capital: Differences between male and female entrepreneurs: Does gender matter?. Small Business Economics, 16(4), pp. 329-345.

World Bank, 2020. Data bank, Gender Statistics, NW Washington, DC: s.n. 